\title{
ANDROGEN AND ESTROGEN RECEPTORS IN PERINATAL FERRET BRAIN $^{1}$
}

\author{
C. C. VITO,$^{*, 2}$ M. J. BAUM $\sharp^{3}$ C. BLOOM, ${ }^{*}$ AND T. O. FOX $^{*, 4}$ \\ * Department of Neuroscience, Children's Hospital, and Department of Neuropathology, Harvard Medical School, Boston, \\ Massachusetts 02115; and $\ddagger$ Department of Nutrition and Food Science, Massachusetts Institute of Technology, \\ Cambridge, Massachusetts 02139
}

Received September 22, 1983; Revised June 25, 1984; Accepted July 19, 1984

\begin{abstract}
Using DNA-cellulose affinity chromatography and either ${ }^{3} \mathrm{H}$-labeled dihydrotestosterone, testosterone, or estradiol, we qualitatively and quantitatively analyzed the androgen- and estrogen-binding activities present in four regions of male and female ferret brain at prenatal, early and late neonatal, and adult ages. The cytosolic androgen- and estrogen-binding activities in ferret brain at all ages studied were qualitatively similar in both sexes and in all brain regions and exhibited characteristics which resemble those of androgen and estrogen receptors from other species, including rodents and nonhuman primates. A developmental analysis indicated that high levels of both androgen and estrogen receptors were present in the hypothalamus-preoptic area as early as 5 days before birth. A significant, transient decline in concentrations of estrogen receptors (approximately 5-fold) occurred in anterior hypothalamus-preoptic area and mediobasal hypothalamus at 12 days of age in both males and females; this phenomenon has not been observed in any other species studied to date. The observed ontogeny of androgen receptors correlates with the known ability of testosterone, acting over postnatal days 5 to 20 , to cause coital masculinization in ferrets, whereas the observed postnatal dip in estradiol receptor concentrations correlates with the inability of estradiol to cause coital masculinization or defeminization of receptive behavior in this species.
\end{abstract}

Several aspects of brain sexual differentiation in ferrets are strikingly different from those in other species such as mice, rats, and hamsters. For example, a critical period of coital masculinization in ferrets occurs during the late neonatal period (Baum et al., 1982; Baum and Erskine, 1984), beginning approximately 5 days postnatally and extending to approximately 20 days after birth; in mice and rats, a critical period occurs perinatally with its onset being prenatal (see Vito and Fox, 1982), while in hamsters a critical period occurs during the early neonatal period (Eaton, 1970; Swanson, 1970), beginning at birth and ending 4 to 5 days later. Also unique to ferrets is the fact that coital masculinization occurs only after exposure to testosterone at late neonatal ages (Baum et al., 1982). Neonatal administration of either dihydrotestosterone or estradiol to female ferrets was ineffective. This is in contrast to mice, rats, and hamsters in which the aromatization of androgens to estrogen has been implicated in the process of coital masculinization (reviewed in Baum, 1979). Furthermore, in contrast to mice, rats, or hamsters, perinatal exposure of male or female

\footnotetext{
${ }^{1}$ This work was supported by United States Public Health Service Grants HD 18660 (C. C. V.), HD 13634 and KO2 MH 03392 (M. J. B.), and HD 18656 (T. O. F.). We gratefully acknowledge the technical assistance of C. Gallagher and M. Kindy.

${ }^{2}$ Present address: VENTREX Laboratories, Inc., 217 Read Street, Portland, ME 04103.

${ }^{3}$ To whom correspondence should be addressed.

${ }^{4}$ Present address: E. K. Shriver Center for Mental Retardation, 200 Trapelo Road, Waltham, MA 02254.
}

ferrets to estrogen or androgen failed to reduce the animals' capacity later to display receptive coital behavior in response to adult treatment with estradiol (i.e., perinatal steroids failed to cause receptive defeminization). Given these observations, we were interested in the possibility that these behavioral characteristics unique to ferrets may be correlated with speciesspecific differences in androgen and estrogen receptor systems in the brain, especially during the critical neonatal period of coital masculinization. In particular, we were interested in the ontogeny of androgen and estrogen receptors and their relationship to both the time course of coital masculinization and gonadal hormone production in male and female ferrets. In order to compare these developmental events in ferrets with similar events in other species, we chose to analyze receptors for both androgens and estrogens in developing and adult ferret brain (male and female) using methods which have proven to be sensitive in the analysis of receptors in mouse (Fox, 1975a, b; Vito and Fox, 1979; Vito et al., 1979), rat (Lieberburg et al., 1980; Vito and Fox, 1979, 1982; Wieland and Fox, 1981a), and hamster brain (Vito et al., 1983).

The experiments described in this report $(a)$ demonstrate the existence of typical androgen and estrogen receptors in adult ferret brain; $(b)$ qualitatively characterize androgen and estrogen receptors in neonatal male and female ferret brain; and (c) quantitatively establish the relationship between age, sex, and receptor concentrations in four regions of ferret brain.

\section{Materials and Methods}

Animals. Pregnant ferrets were purchased from Marshall Research Farm (North Rose, NY), approximately 2 weeks before the expected 
day of delivery (gestation $=42$ days; birth $=0$ days of age). Pregnant and lactating females were provided with nest boxes in individual cages, kept under a 16-hr/8-hr light/dark cycle, and fed Purina Cat Chow and canned cat food.

Chemicals. ${ }^{3} \mathrm{H}$-labeled hormones were obtained from Amersham (Arlington Heights, IL) and New England Nuclear (Boston, MA). Stocks of $\left[2,4,6,7 \cdot{ }^{3} \mathrm{H}\right]$ estradiol and $\left[2,4,6,7,16,17-{ }^{3} \mathrm{H}\right]$ estradiol were 107 and $140 \mathrm{Ci} / \mathrm{mmol}$, respectively; stocks of $\left[1,2,4,5,6,7-{ }^{3} \mathrm{H}(N)\right]-5$ - $\alpha$-dihydrotestosterone (DHT) and $\left[1,2,4,5,6,7,16,17{ }^{3} \mathrm{H}\right] \mathrm{DHT}$ were 143 and 208 $\mathrm{Ci} / \mathrm{mmol}$, respectively; and stocks of $\left[1,2,6,7-{ }^{3} \mathrm{H}\right]$ testosterone (TFS) and $\left[1,2,6,7,16,17 \cdot{ }^{3} \mathrm{H}\right] \mathrm{TES}$ were 107 and $152 \mathrm{Ci} / \mathrm{mmol}$, respectively. Stocks of ${ }^{3} \mathrm{H}$-labeled hormones were checked for purity and were repurified, if necessary, by high performance liquid chromatography as previously described (Wieland and Fox, 1981b).

Buffers. Extract buffer and elution buffer contained $50 \mathrm{~mm}$ Tris$\mathrm{HCl}, \mathrm{pH} 8.1\left(21^{\circ} \mathrm{C}\right), 1 \mathrm{mM}$ EDTA, $1 \mathrm{mM}$ mercaptoethanol, $10 \%(\mathrm{v} / \mathrm{v})$ glycerol, and $\mathrm{NaCl}$ as indicated. This buffer is suitable for solubilization of available receptors into the cytosolic fraction of tissue homogenates (Fox, 1975b; Fox et al., 1982) and is used at ionic strengths low enough for efficient chromatography on DNA-cellulose columns (Fox and Savakis, 1983). The conductivity of buffers and samples ( $10 \mu$ ldiluted into $500 \mu \mathrm{l}$ of deionized water) was measured using a Radiometer meter; $\mathrm{NaCl}$ concentrations were determined with a standard curve.

Brain dissection and preparation of cytosol extracts. To obtain prenatal brain tissues, pregnant females were anesthetized with pentobarbital $(45 \mathrm{mg} / \mathrm{kg}) 5$ days before the expected day of parturition ( -5 days of age). The uterus and its contents were removed via a midline incision, and the kits were delivered and immediately decapitated. Other groups of ferrets were decapitated at several different postnatal ages $(7,10$, 12 , and 15 days of age). Adult male and female ferrets, gonadectomized with pentobarbital anesthesia approximately 1 week before brain dissections, were killed by $\mathrm{CO}_{2}$ asphyxiation followed by decapitation. All ferrets were killed 4 to $6 \mathrm{hr}$ into the light phase of the day/night cycle.

Brains were removed from all animals immediately after decapitation, taking care first to sever the pituitary stalk. Brains were placed ventral surface facing upward on an ice-cold glass plate. A no. 11 surgical blade was used for all dissections. Figure 1 illustrates the dissection procedures followed.

At -5 days of age, only a single slab of brain was isolated by making one coronal slice $2 \mathrm{~mm}$ in front of the optic chiasm and a second slice at the caudal edge of the mammillary bodies. This slab was turned on end, and a single horizontal slice was made at the level of the anterior commissure. The combined hypothalamus and preoptic area $(\mathrm{H}+$ POA) was isolated from this slab by making two lateral slices at the hypothalamic fissures. The remaining two pieces of lateral tissue were combined and designated as temporal lobe (TL). Cerebral cortex (CTX) was isolated from this slab of tissue by making a single horizontal slice at the level of the corpus callosum.

For ferrets of each sex at each perinatal age, brain regions from three to eight animals were pooled in a tube containing cold extract buffer which was immediately frozen on dry ice and stored in either liquid nitrogen $\left(-196^{\circ} \mathrm{C}\right)$ or in a Reven freezer $\left(-80^{\circ} \mathrm{C}\right)$. In some instances tissue was not stored frozen but was kept instead in buffer on ice for approximately $2 \mathrm{hr}$ before assay. We have observed no receptor differences (quantitative or qualitative) in homogenates obtained from tissues frozen for storage versus those not frozen prior to homogenization.

Preparation of cytosol extracts and all subsequent manipulations were performed at $2^{\circ} \mathrm{C}$. To prepare cytosol extracts, tissues were homogenized in buffer containing $10 \mathrm{~mm} \mathrm{NaCl}$ using Kontes/"Teflonglass homogenizers; the initial homogenate was then transferred to a centrifuge tube, followed by two half-volume rinses of the homogenizer. The tissue-to-buffer ratio of the complete homogenate was $450 \mathrm{mg}$ of tissue (wet weight) $/ \mathrm{ml}$ of buffer. The homogenate was then centrifuged at $140,000 \times g$ for $60 \mathrm{~min}$ at $2^{\circ} \mathrm{C}$. The resulting cytosol was then collected, samples $(5 \mu$ ) in duplicate) were removed for protein content determination (Lowry et al., 1951), and the remainders were prepared for DNA-cellulose affinity chromatography.

DNA-cellulose affinity chromatography. Cytosols were collected, transferred to polystyrene tubes (Sarstedt), and incubated with either $\left[{ }^{3} \mathrm{H}\right]$ estradiol, $\left[{ }^{3} \mathrm{H}\right] \mathrm{DHT}$, or $\left[{ }^{3} \mathrm{H}\right] \mathrm{TES}$. Following a 60 -min incubation at $2^{\circ} \mathrm{C}$, cytosols were applied to DNA-cellulose columns (equilibrated with buffer containing $10 \mathrm{mM} \mathrm{NaCl}$ ) and allowed to enter the columns by gravity flow. Prior to and subsequent to layering the cytosol, $200 \mu \mathrm{l}$ of buffer containing the appropriate ${ }^{3} \mathrm{H}$-labeled hormone at each respective concentration were applied to the column; these steps ensure that the column and its contents are exposed to a uniform concentration of ${ }^{3} \mathrm{H}$-labeled hormone. The columns containing the ${ }^{3} \mathrm{H}$-labeled cytosol were transferred to an incubator at 20 to $21^{\circ} \mathrm{C}$. After $60 \mathrm{~min}$, the columns were returned to the cold room $\left(2\right.$ to $\left.4^{\circ} \mathrm{C}\right)$ and allowed to cool for $30 \mathrm{~min}$. The columns were then washed with buffer containing $10 \mathrm{~mm} \mathrm{NaCl}(\sim 16$ column volumes for $16 \mathrm{hr})$ to remove free radioactivity and those cytosol components which did not adhere to DNAcellulose under these experimental conditions.

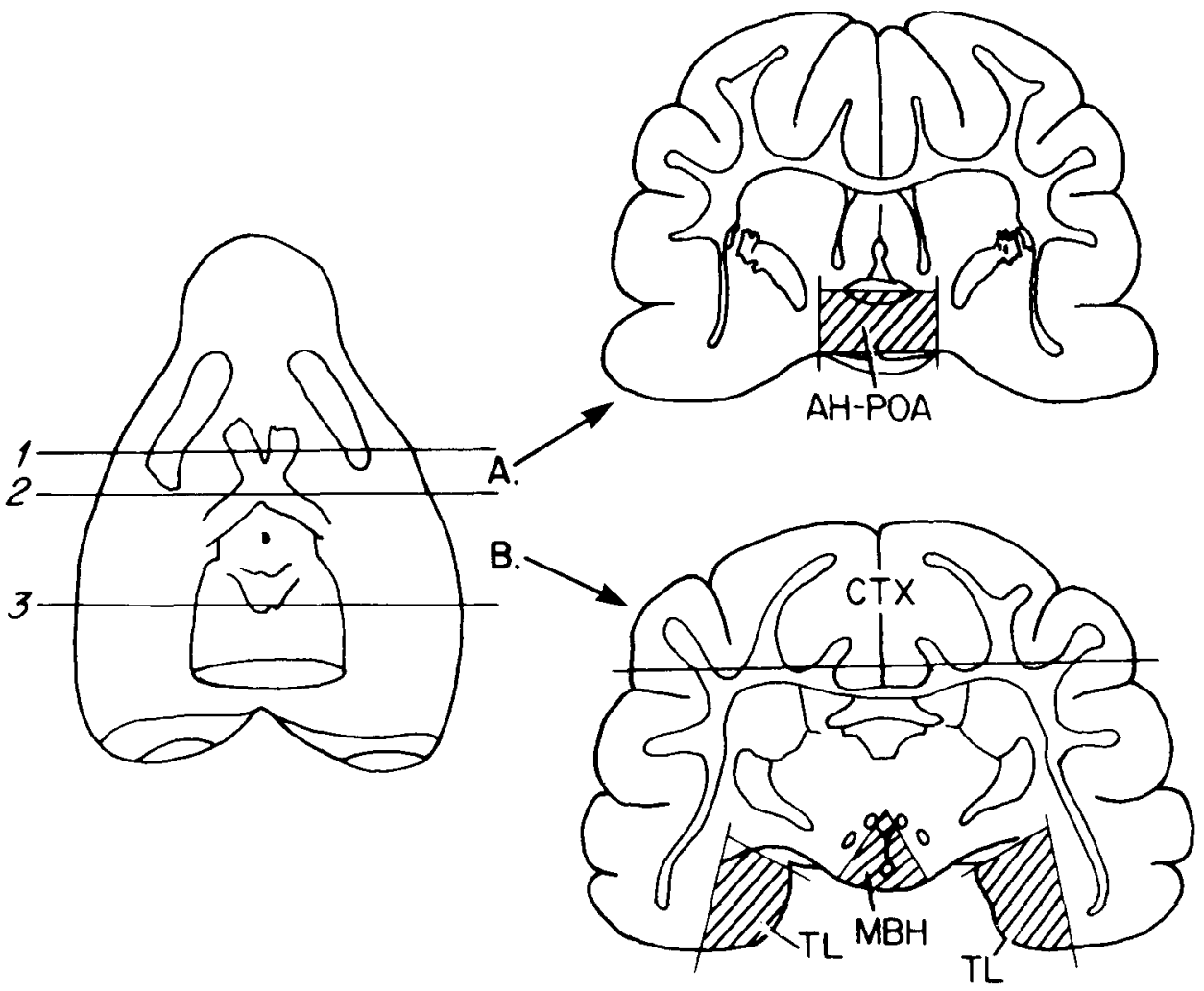

Figure 1. Regional dissection of postnatal ferret brain. Dissection procedures for obtaining the AH-POA, MBH, TL, and CTX were as follows. For all postnatal brains, three coronal slices were made: one $2 \mathrm{~mm}$ in front of the rostral border of the optic chiasm (line 1 ), a second at the caudal edge of the optic chiasm (line 2), and a third at the caudal edge of the mammillary bodies (line 3 ). This procedure thereby isolated two slabs of brain ( $A$ and $B$ ). The AH-POA was isolated from slab A by making one cut at the level of the anterior commissure and two lateral cuts $2 \mathrm{~mm}$ on either side of the midline. The MBH was isolated from slab B by making two intersecting diagonal slices extending from the lateral edge of the chiasm to the top of the third ventricle. The optic nerves and the chiasm were dissected free from the $\mathrm{AH}-\mathrm{POA}$ and $\mathrm{MBH}$, respectively. The TL was isolated bilaterally from slab B by making two intersecting slices, one originating at the most lateral edge of the hypothalamus and extending upward and laterally, and a second originating at the base of the temporal lobe and extending straight upward. Finally, the CTX was isolated from slab B by making a single horizontal slice across the tissue at the level of the corpus callosum. 
The ${ }^{3} \mathrm{H}$-labeled hormone-receptor complexes which adhered to DNAcellulose were eluted with a linear concentration gradient of $\mathrm{NaCl}$. Fractions (approximately equivalent to $1 / 4$ column volume) were collected and aliquots were removed to determine $\mathrm{NaCl}$ concentration. Radioactivity was measured in $5 \mathrm{ml}$ of Omnifluor (New England Nuclear)-toluene liquid scintillation fluid using a Beckman LS 233 liquid scintillation counter; the counting efficiency for tritium was $39 \%$. All receptor values in this report were obtained by DNA-cellulose chromatography. Since these could represent a subset of total in situ receptor, detected differences reflect both absolute receptor amounts and plausible changes in their DNA-binding activity. Further experimental considerations pertinent to the chromatography of radiolabeled cytosol extracts are discussed elsewhere (Vito et al., 1979; Vito and Frv, 1982; Fox and Savakis, 1983). Results are displayed in femtomoles per milligram of protein. Although not shown in the text, data on the ontogeny of estrogen and androgen receptors in different brain regions were also calculated in femtomoles per tissue pool. Results expressed in both ways were analyzed across the various postnatal ages using the Kruskal-Wallis one-way analysis of variance by ranks. Provided the resultant $H$ value was significant at $p<0.05$, subsequent individual groups' comparisons were made using two-tailed Mann-Whitney $U$ tests.

\section{Results}

Qualitative characterization of hormone-binding activities in adult ferret hrain. Using DNA-cellulose affinity chromatography, we characterized the androgen- and estrogen-binding activities in various regions of adult ferret brain. Figure 2 illustrates representative elution profiles obtained during chromatography of anterior hypothalamus-preoptic area (AH-POA) extracts (from gonadectomized adult males) labeled with either ${ }^{3} \mathrm{H}$-androgens or ${ }^{3} \mathrm{H}$-estrogen. In the case of those extracts labeled with $\left[{ }^{3} \mathrm{H}\right] \mathrm{DHT}$ or $\left[{ }^{3} \mathrm{H}\right] \mathrm{TES}$, a major peak of androgenbinding activity eluted within the 120 to $140 \mathrm{mM}$ region of the $\mathrm{NaCl}$ elution gradient. Qualitatively, the ability to $(a)$ bind both DHT and TES, $(b)$ adhere to DNA-cellulose, and $(c)$ exhibit a reliable and reproducible elution maxima at 120 to $140 \mathrm{mM} \mathrm{NaCl}$, each, is characteristic of a receptor-like androgen-binding activity. To further assess the receptor qualities of this activity in ferret AH-POA, we performed a parallel analysis of androgen binding in mouse brain, also using DNA-cellulose as previously described for mouse androgen receptors (Vito et al., 1979). In this direct comparison (data not shown), we found that the androgen-binding activities in ferret brain were qualitatively indistinguishable from those in mouse brain, both in terms of hormone-binding specificity and behavior during DNA-cellulose affinity chromatography. Also, we have found that the androgen-binding activities in mediobasal hypothalamus (MBH), TL, and CTX are qualitatively similar to those in $\mathrm{AH}-\mathrm{POA}$ and that the androgen-binding activities in male ferret brain are similar to those in female ferret brain. Thus, in our qualitative characterization of androgen receptors from ferret brain, we have found no evidence to suggest species, sex, or regional differences.

As illustrated in Figure 2, estrogen-binding activity was also detectable in extracts of adult ferret AH-POA and was readily distinguished from the androgen-binding activities in ferret AH-POA by virtue of its different elution behavior. When analyzed using DNA-cellulose affinity chromatography, the $\left[{ }^{3} \mathrm{H}\right]$ estradiol-binding activity in ferret AH-POA exhibited an elution maximum at the $200 \mathrm{mM}$ region of the $\mathrm{NaCl}$ elution gradient. The ability both to adhere to DNA-cellulose and to reproducibly exhibit this specific elution behavior is characteristic of estrogen receptor activity. Furthermore, in a direct comparison of ferret brain and mouse brain (data not shown), the qualitative characteristics of estrogen receptor from ferret brain were indistinguishable from those in mouse brain when analyzed using DNA-cellulose affinity chromatography; and, as is true for ferret androgen receptors, we have detected no

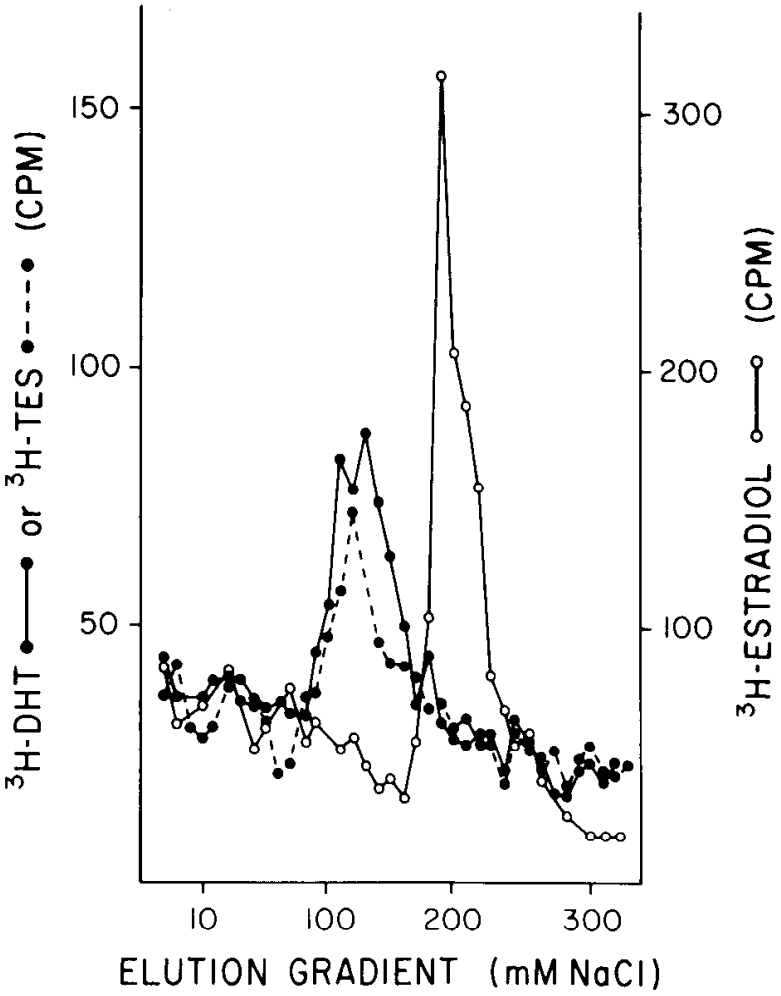

Figure 2. DNA-cellulose affinity chromatography of androgen and estrogen receptors from cytosol extracts of adult male ferret AH-POA. A cytosol extract of AH-POA from gonadectomized adult male ferrets was prepared as described under "Materials and Methods." Aliquots were then incubated with either $\left[{ }^{3} \mathrm{H}\right] \mathrm{DHT}\left(143 \mathrm{Ci} / \mathrm{mmol} ;-1{ }^{3} \mathrm{H}\right]$ TES (152 Ci/mmol; - - - ) , or $\left[{ }^{3} \mathrm{H}\right]$ estradiol $(140 \mathrm{Ci} / \mathrm{mmol} ; \mathrm{O}-\mathrm{O})$ at final concentrations of $10 \mathrm{nM}$. Following a 60 -min incubation at 2 to $4^{\circ} \mathrm{C}$, each aliquot (containing approximately the equivalent of 1 block of AH-POA) was layered on a column of DNA-cellulose $(5 \mathrm{ml}$ packed volume) and further treated as described under "Materials and Methods." The androgen- and estrogen-binding activities which adhered to the DNA-cellulose were then eluted with a linear concent ration gradient of $\mathrm{NaCl}$ (equivalent to 8 column volumes), ranging from 10 to $400 \mathrm{mM}$. Fractions $(1.25 \mathrm{ml})$ were collected, and the $\mathrm{NaCl}$ concentration and the radioactivity per fraction were determined as described under "Materials and Methods." The peaks of bound $\left[{ }^{3} \mathrm{H}\right] \mathrm{DHT}$ and $\left[{ }^{3} \mathrm{H}\right] \mathrm{TES}$ which elute at 120 to $140 \mathrm{~mm} \mathrm{NaCl}$ are equivalent to 2.2 and $1.2 \mathrm{~mol} /$ mg of tissue $\left(\times 10^{17}\right)$, respectively. The peak of bound $\left[{ }^{3} \mathrm{H}\right]$ estradiol which elutes at 200 to $220 \mathrm{mM} \mathrm{NaCl}$ is equivalent to $5.9 \mathrm{~mol} / \mathrm{mg}$ of tissue $\left(\times 10^{17}\right)$.

qualitative species, sex, or regional differences in brain estrogen receptors in adult ferrets.

Thus, on the basis of these data, we conclude that adult male and female ferret hrain contains both androgen- and estrogenbinding activities which are typical of the receptors present in the brains of subavian (Salhanick et al., 1979), avian (Siegel et al., 1983), rodent (Lieberburg et al., 1980; Vito and Fox, 1982; Vito et al., 1983), and nonhuman primate (Pomerantz et al., 1985) species.

Qualitative characterization of hormone-binding activities in neonatal ferret brain. Figure 3 illustrates representative elution profiles of the androgen- and estrogen-binding activities in MBH extracts from 7-day-old male ferrets obtained using DNA-cellulose affinity chromatography. When labeled with either $\left[{ }^{3} \mathrm{H}\right] \mathrm{DHT}$ or $\left[{ }^{3} \mathrm{H}\right] \mathrm{TES}$, the ${ }^{3} \mathrm{H}$-androgen-binding activity adhered to DNA-cellulose and reproducibly eluted within the 120 to $140 \mathrm{~mm}$ region of the $\mathrm{NaCl}$ elution gradient. The binding specificity and elution behavior of the androgen-binding activities detected in perinatal extracts were similar to those in extracts of adult ferret brain (refer to Fig. 2); when analyzed in 


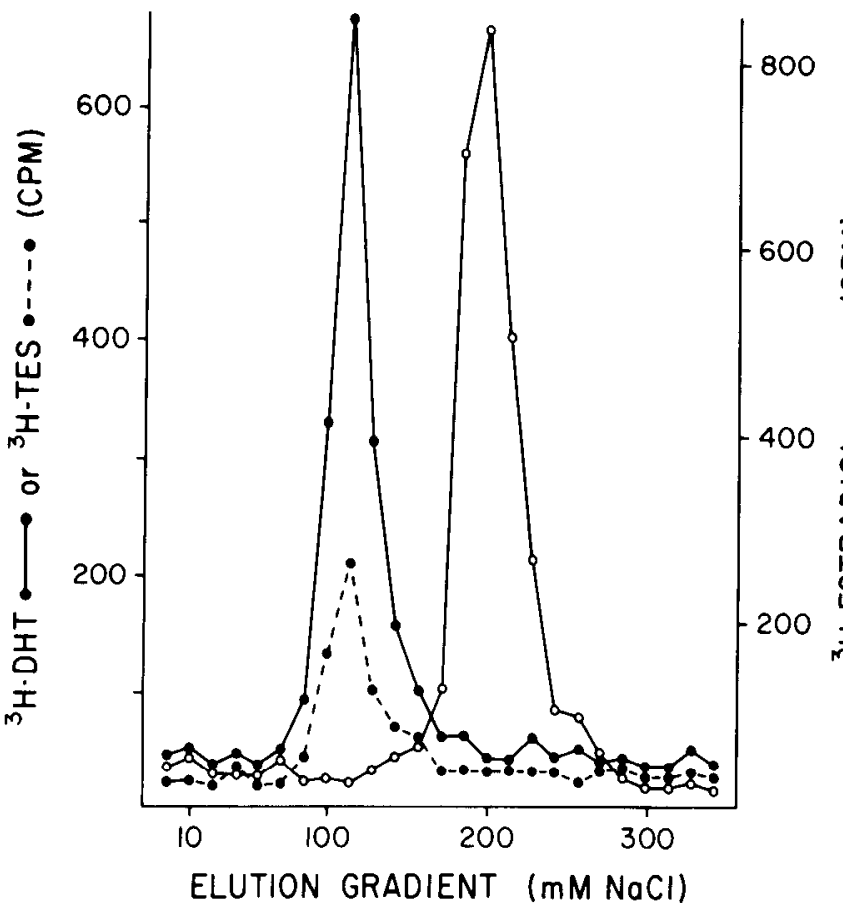

Figure 3. DNA-cellulose affinity chromatography of androgen and estrogen receptors from cytosol extracts of neonatal male ferret $\mathrm{MBH}$ Cytosol extracts of $\mathrm{MBH}$ from 7-day-old male ferrets were prepared as described under "Materials and Methods." Aliquots were then incubated with either $\left[{ }^{3} \mathrm{H}\right] \mathrm{DHT}(208 \mathrm{Ci} / \mathrm{mmol} ;-10),\left[{ }^{3} \mathrm{H}\right] \mathrm{TES}(107 \mathrm{Ci} /$ $\left.\mathrm{mmol} ;{ }_{-}-1\right)$, or $\left[{ }^{3} \mathrm{H}\right]$ estradiol $(107 \mathrm{Ci} / \mathrm{mmol} ; \mathrm{O}-\mathrm{O})$ at final concentrations of $10 \mathrm{nM}$. Following a 60 -min incubation at 2 to $4^{\circ} \mathrm{C}$, each aliquot (containing the equivalent of 4 blocks of $\mathrm{MBH}$ ) was layered on a column of DNA-cellulose (5 ml packed volume) and further treated as described under "Materials and Methods." The androgen- and estrogen-binding activities which adhered to the DNA-cellulose were then eluted and distinguished with a linear concentration gradient of $\mathrm{NaCl}$ (equivalent to 6 column volumes), ranging from 10 to $400 \mathrm{~mm}$. Fractions $(1.25 \mathrm{ml})$ were collected, and the $\mathrm{NaCl}$ concentration and the radioactivity per fraction were determined as described under "Materials and Methods." The peaks of bound $\left[{ }^{3} \mathrm{H}\right]$ DHT and $\left[{ }^{3} \mathrm{H}\right]$ TES which elute at 120 to $140 \mathrm{mM} \mathrm{NaCl}$ are equivalent to 4.0 and $2.5 \mathrm{~mol} / \mathrm{mg}$ of tissue $\left(\times 10^{17}\right)$, respectively. The peak of bound $\left[{ }^{3} \mathrm{H}\right]$ estradiol which elutes at 200 to $220 \mathrm{mM} \mathrm{NaCl}$ is equivalent to $9.5 \mathrm{~mol} / \mathrm{mg}$ of tissue $(\times$ $10^{17}$ ).

parallel, the binding activities in perinatal extracts were qualitatively indistinguishable from those in adult extracts. Moreover, these characteristics were qualitatively typical of the androgen-binding activities detected in ferret brain at all other perinatal ages tested (from -5 to 15 days of age), and they are similar to those in developing rodent (Vito et al., 1979; Lieberburg et al., 1980; Vito and Fox, 1982; Vito and DeBold, 1983) and primate (Pomerantz et al., 1985) brain. Furthermore, we have detected no qualitative sex or regional differences in the androgen-binding activities in ferret perinatal brain extracts.

As in the adult ferret brain, the estrogen-binding activity in 7-day-old ferret brain was readily distinguishable from the androgen-binding activities by virtue of its different elution behavior. When labeled with $\left[{ }^{3} \mathrm{H}\right]$ estradiol and analyzed using DNA-cellulose affinity chromatography, the estrogen-binding activity in neonatal ferret $\mathrm{MBH}$ exhibited an elution maximum at $200 \mathrm{~mm} \mathrm{NaCl}$ which is characteristic of the estrogen receptor in adult ferret brain and in developing rodent (Fox, 1975a; MacLusky et al., 1979a, b; Vito and Fox, 1982; Vito and DeBold, 1983) and primate (Pomerantz et al., 1985) brain.

These data, suggesting the existence of an estrogen receptor in developing ferret brain, are consistent with those of a previously published report (Holbrook and Baum, 1983) in which the presence of estrogen receptors in prenatal and neonatal ferret brain was established using Sephadex LH20 gel filtration as well as sucrose density gradient centrifugation; our findings also confirm the observation (Holbrook and Baum, 1983) that no qualitative sex or regional differences in estrogen receptors are detectable in developing ferret brain.

Ontogeny of androgen and estrogen receptors in ferret brain. The development of both androgen and estrogen receptor in various brain regions is depicted in Figure 4 . The mean values at each age were derived by combining individual male and

\section{ANDROGEN}
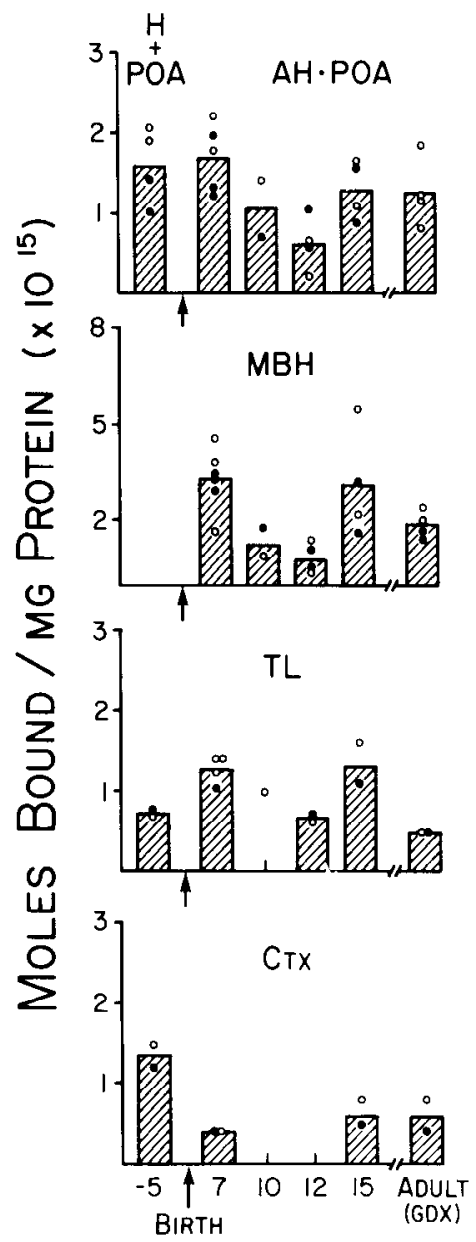

\section{ESTROGEN}
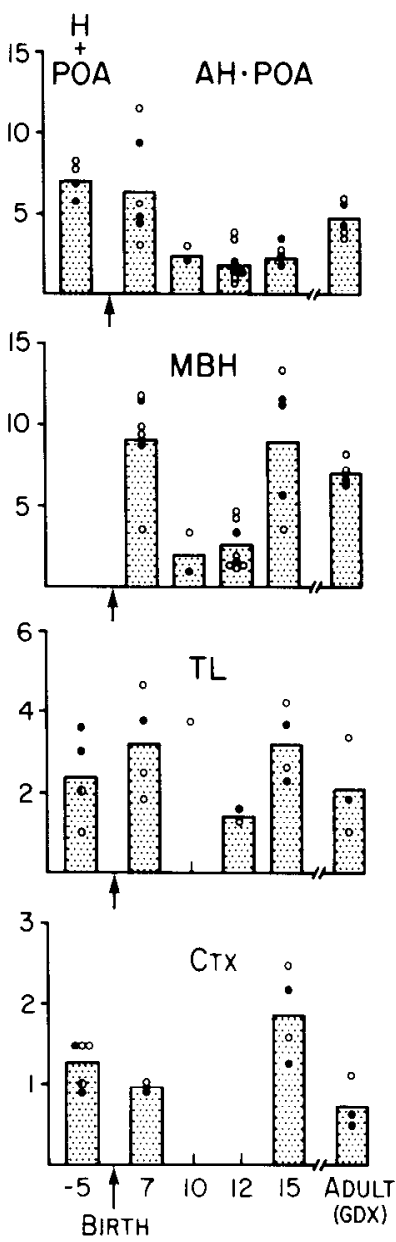

\section{AgE IN DAYS}

Figure 4. Androgen and estrogen receptors in male and female ferret brain: ontogeny and regional distribution. The ordinate indicates the concentrations (moles) of bound hormone per milligram of protein $(X$ $10^{15}$ ) in cytosol extracts of pooled male $(-$ and pooled female $(O)$ ferret brains. The bars represent mean values determined by combining all male and female values depicted at each age. Quantitation of bound hormone was achieved using DNA-cellulose affinity chromatography; the concentrations of androgen- and estrogen-binding activities in cytosol extracts were determined using saturating concentrations of $\left[{ }^{3} \mathrm{H}\right] \mathrm{DHT}$ ( hatched bars) or $\left[{ }^{3} \mathrm{H}\right]$ estradiol (stippled bars), respectively. Birth ( 0 days of age) is indicated by the arrows. At 5 days before birth $(-5)$, extracts were made from the $\mathrm{H}+\mathrm{POA}$ whereas, at all other ages ( 7 days of age through adulthood), separate extracts were made from the AH-POA and the MBH. Extracts of TL were used at prenatal, postnatal, and adult ages. At -5 days of age, CTX represents the entire cerebral cortex; at all other ages, CTX represents parietal cortex. At -5 to 15 days of age, brains were obtained from gonadally intact male and female ferrets; at adult ages, brains were obtained from gonadectomized $(G D X)$ males and females. 
TABLE I

Sex comparison of androgen and estrogen receptor concentrations in neonatal ferret brain (postnatal days 7 to 15 combined)

\begin{tabular}{|c|c|c|c|c|c|c|}
\hline \multirow{2}{*}{ Sex } & \multicolumn{2}{|c|}{$\begin{array}{c}\text { Anterior Hypothalamus-Preoptic } \\
\text { Area }\end{array}$} & \multicolumn{2}{|c|}{ Mediobasal Hypothalamus } & \multicolumn{2}{|c|}{ Temporal Lobe } \\
\hline & Androgen & Estrogen & Androgen & Estrogen & Androgen & Estrogen \\
\hline & \multicolumn{6}{|c|}{ fmol of steroid bound/mg of cytosol protein } \\
\hline Male & $\begin{array}{c}1.15 \pm 0.17^{a} \\
(8)^{b}\end{array}$ & $\begin{array}{l}3.13 \pm 0.74 \\
\quad(11)\end{array}$ & $\begin{array}{c}2.23 \pm 0.43 \\
(8)\end{array}$ & $\begin{array}{l}5.86 \pm 1.46 \\
\quad(10)\end{array}$ & $\begin{array}{c}0.95 \pm 0.13 \\
(3)\end{array}$ & $\begin{array}{c}2.86 \pm 0.63 \\
(4)\end{array}$ \\
\hline Female & $1.28 \pm 0.28$ & $\begin{array}{l}3.56 \pm 1.04 \\
(10)\end{array}$ & $2.53 \pm 0.70$ & $\begin{array}{c}6.01 \pm 1.35 \\
(11)\end{array}$ & $\begin{array}{c}1.20 \pm 0.16 \\
(6)\end{array}$ & $\begin{array}{c}3.02 \pm 0.51 \\
\quad(7)\end{array}$ \\
\hline
\end{tabular}

${ }^{a}$ Data are expressed as mean \pm SEM. None of the sex differences were statistically significant $(p>0.10$, Mann-Whitney $U$ tests, two-tailed).

${ }^{b}$ Numbers in parentheses, number of independent determinations on pools of male or female tissues.

female determinations, since no significant sex differences in the concentration of either type of receptor were apparent in AH-POA, MBH, or TL at postnatal days 7, 10, 12, and 15 combined (Table I). It is evident from the data summarized in Figure 4 that both androgen and estrogen receptors were present in ferret brain at the earliest age sampled (e.g., day -5$)$ and that both types of receptor remained detectable throughout postnatal development, including the critical neonatal period of coital masculinization. An overall comparison of estrogen receptor concentrations (data expressed in femtomoles per milligram of protein) across all postnatal ages revealed a significant change in AH-POA (Kruskal-Wallis $H=17.35, d f=$ $4, p<0.01)$ and in $\mathrm{MBH}(H=16.23, d f=4, p<0.01)$, but not in TL. Too few determinations were done in CTX to allow meaningful statistical comparisons. Individual age group comparisons with Mann-Whitney $U$ tests showed that estrogen receptor concentrations in AH-POA were significantly lower at postnatal days 12 and 15 than at day 7 or in adulthood ( $p<$ 0.01 ). Likewise, estrogen receptor concentrations in $\mathrm{MBH}$ were significantly lower at postnatal day 12 than at day 7, day 15, or in adulthood $(p<0.01)$.

A similar pattern of statistical differences was obtained when the estrogen receptor data were expressed in femtomoles per tissue pool (data not displayed). Overall statistical comparisons revealed significant effects in AH-POA $(H=11.61, d f=4, p<$ $0.05)$ and $\mathrm{MBH}(H=25.86, d f=4, p<0.01)$. Subsequent group comparisons showed that estrogen receptor content in $\mathrm{AH}$ POA was significantly lower at postnatal day 12 than at day 7 or 15 , or in adulthood $(p<0.05)$. Likewise, for $\mathrm{MBH}$, estrogen receptor content was significantly lower on day 12 than on day 7 , day 15 , or in adulthood $(p<0.01)$. Saturation analysis carried out using either AH-POA or MBH taken from males and females killed on day 12 revealed no apparent change in the affinity of estrogen receptors for $\left[{ }^{3} \mathrm{H}\right]$ estradiol (data not shown).

Analysis of the ontogeny of androgen receptors, when data were expressed in femtomoles per milligram of protein, also revealed a dip in receptor concentration at days 10 to 12 , with significant variations being detected in AH-POA $(H=9.81, d f$ $=4, p<0.05), \mathrm{MBH}(H=10.84, d f=4, p<0.05)$, and TL $(H$ $=8.25, d f=3, p<0.05$ ). Subsequent group comparisons showed that androgen receptor concentrations in AH-POA were lower at day 12 than at day 7 , day 15 , or in adulthood $(p<0.05)$. In $\mathrm{MBH}$, androgen receptor concentrations on day 12 were lower than at day 7 , day 15 , or in adulthood $(p<0.01)$. Androgen receptor concentrations in TL on days $10+12$ were significantly lower than at day 7 . The reliability of the above reductions in androgen receptor concentration around day 12 was brought into question, however, after reanalysis of the data expressed in femtomoles per tissue pool. Again, overall statistical comparisons revealed a significant effect of postnatal age on androgen receptor content of $\mathrm{AH}-\mathrm{POA}(H=10.99, d f=4$, $p<0.05), \mathrm{MBH}(H=12.46, d f=4, p<0.02)$, and TL $(H=$ $10.44, d f=3, p<0.05)$. However, individual comparisons of androgen receptor content for each region revealed a different pattern of differences from that which was obtained when the results were expressed in femtomoles per milligram of protein. Thus, for AH-POA, receptor content at days 7 and 12 was lower $(p<0.05)$ than at day 15 ; for $\mathrm{MBH}$, adult content was significantly lower than for day $15(p<0.05)$, and for TL, day $10+12$ content was significantly lower than day 7 content $(p$ $<0.05$ ). We place little emphasis on the potential biological significance of any postnatal variations in brain androgen receptor content, because the absolute variation in receptor content was lower compared to the estrogen receptor data and because there was the discrepancy in the age profile of androgen receptor results, depending on how the data are expressed.

Preliminary experiments, in which we compared intact versus neonatally (day 5) gonadectomized ferrets (males and females separately) killed at 11, 12, or 21 days of age, revealed no apparent differences in detectable androgen or estrogen receptor concentrations in any brain region tested (data not shown).

\section{Discussion}

Androgen- as well as estrogen-binding activities measured in different regions of ferret brain during development exhibited characteristics which are identical to those of androgen and estrogen receptors previously characterized during perinatal development in mouse, rat, and hamster brain regions. As for those rodent species, the present study indicated that, qualitatively, the androgen and estrogen receptors present in ferret brain were not distinguishable on the basis of sex, age, or brain region. There were, however, important quantitative differences between the ferret and the three rodent species previously studied in the concentration profile of estrogen receptors as well as in the temporal relationships during development in the initial appearance of both estrogen and androgen receptors and the onset of the critical perinatal period of coital masculinization.

The concentrations of estrogen receptor measured in different subcortical brain regions of male and female ferrets prenatally as well as 7 days postnatally were notably higher than the concentration of this receptor previously measured in mouse, rat, or hamster at comparable ages. In contrast to these rodent species, however, estrogen receptor concentrations in AH-POA and MBH declined approximately 5-fold in the middle of the postnatal period of coital masculinization. As a consequence, the estrogen receptor concentrations during this postnatal period in ferret brain were markedly lower than those in either mouse or rat brain during their critical period of brain differentiation (Vito and Fox, 1982). Likewise, as a consequence of this reduction, the ratio of hypothalamic androgen to estrogen receptor was higher in ferrets than in mice, rats, or hamsters during postnatal development.

It seems unlikely that the decline in estrogen receptor concentrations observed on postnatal day 12 reflects a technical inability to detect receptors bound to endogenous steroids, 
because there is no correlation between the levels of estrogen receptor measured in the present study and the availability of estrogen to interact with these receptors. For example, we detected the highest concentrations of estrogen receptor in various brain regions at -5 days, an age when plasma levels of estradiol and estrone (Erskine and Baum, 1984) are as high in both sexes as those measured in adult female ferrets in estrus. By contrast, we detected the lowest concentration of estrogen receptors at postnatal day 12 , when plasma concentrations of estradiol are as low as the levels measured in ovariectomized females. Similarly, there is no apparent correlation between the availability of estrogen synthesized locally in hypothalamic tissues from circulating testosterone and the concentration of estrogen receptor measured in various brain regions across perinatal life. High levels of aromatase activity were measured in $\mathrm{H}+\mathrm{POA}$ (prenatally) and in AH-POA and MBH (postnatally) in ferrets of both sexes (Canick et al., 1984). Plasma concentrations of testosterone were higher (in both sexes) at day -5 than at any other perinatal age (Erskine and Baum, 1982); yet the dip in estrogen receptor concentration occurred at postnatal day 12 . Finally, the concentration of estrogen receptors in $\mathrm{AH}-\mathrm{POA}$ and $\mathrm{MBH}$ was not affected in the present study by neonatal gonadectomy of either sex.

Previous research has shown that, in contrast to rodent species such as the rat, in which estrogenic metabolites of TES contribute to the masculinization of coital behavior (reviewed in Baum, 1979), the male ferret is not significantly masculinized by the action of estradiol (Baum et al., 1982, 1983) during the critical period for this process, which extends between postnatal days 5 and 20. Likewise, in rodent species the formation of estrogenic metabolites of TES in developing subcortical brain regions is associated with the defeminization of receptive behavioral capacity in males. In ferrets, estrogens given shortly after birth lacked the ability to defeminize receptive behavior in females, and males normally fail to undergo receptive defeminization. An obvious overlap exists in rats between the increasing concentration of hypothalamic estrogen receptor previously detected perinatally and the timing of the critical periods for both coital masculinization and receptive defeminization. Likewise, in ferrets the inability of estrogen exposure neonatally to cause either coital masculinization or receptive defeminization is correlated with the reduction in estrogen receptor concentration seen in both males and females around postnatal day 12 .

The significance in both sexes of the comparatively high concentration of estrogen receptors in $\mathrm{H}+$ POA prenatally, coupled with the availability of high levels of estrogen, either via the circulation or via neural aromatization of TES precursor, is not evident at present. It is possible that estrogen acts in the brain of both sexes to promote the formation of neural connections which later control a variety of behavioral and neuroendocrine functions which are not sexually dimorphic. Both the activity of aromatase (Canick et al., 1984) and plasma testosterone concentrations (Erskine and Baum, 1982) are higher at day -5 in males than in females, suggesting that the amount of estrogen available to interact with neural estrogen receptors at this age may be greater in males than in females. Recent evidence suggests that male ferrets normally are sensitized during the late prenatal/early neonatal period to respond more efficiently than females to the masculinizing action of testosterone on coital behavior potential between postnatal days 5 and 20 (Baum and Erskine, 1984). Other evidence suggests that male ferrets undergo a process of defeminization during this same late prenatal/early postnatal period which leads them to display lower levels of proceptive feminine sexual behavior in adulthood (Baum et al., 1985). Either of these functions could result from an interaction of estrogen and estrogen receptors in the male ferret brain.

Like estrogen receptors, androgen receptors were readily measured in various brain regions of both male and female ferrets at the earliest perinatal age studied (day -5 ). They subsequently remained detectable throughout perinatal life, although there were some variations in androgen receptor content during the postnatal period. However, unlike the data for estrogen receptors, the pattern of variation in androgen receptors varied considerably depending on whether the results were expressed in femtomoles of $\left[{ }^{3} \mathrm{H}\right] \mathrm{DHT}$ bound per milligram of cytosol protein or per tissue pool. Regardless of how the data were expressed, the magnitude of the postnatal variation in androgen receptor content never approached that seen for estrogen receptors over the same period. As is true for androgen receptors studied in brain tissues of other species (Fox, 1975b; Attardi and Ohno, 1976; Kato, 1976; Wieland and Fox, 1979; Lieberburg et al., 1980), the androgen receptors isolated in both perinatal and adult ferret brain regions bound both TES and DHT. Studies already cited suggest that TES but not DHT normally causes coital masculinization in the developing male ferret. Certainly, the differential ability of these two androgens to cause this aspect of brain sexual differentiation in males cannot be explained on the basis of the present findings. The concentrations of androgen receptor at prenatal and early postnatal ages were notably higher in ferret brain regions than in comparable regions of rat or mouse brain at this period. The high levels of androgen receptor in ferret brain may contribute to the ability of testosterone to organize brain mechanisms controlling the expression of masculine coital behavior in this species.

\section{References}

Attardi, B., and S. Ohno (1976) Androgen and estrogen receptors in the developing mouse brain. Endocrinology 99: 1279-1290.

Baum, M. J. (1979) Differentiation of coital behavior in mammals: A comparative analysis. Neurosci. Biobehav. Rev. 3: 265-284

Baum, M. J., and M. S. Erskine (1984) Effect of neonatal gonadectomy and administration of testosterone on coital masculinization in the ferret. Endocrinology, in press.

Baum, M. J., C. A. Gallagher, J. T. Martin, and D. A. Damassa (1982) Effects of testosterone, dihydrotestosterone, or estradiol adminis tered neonatally on sexual behavior of female ferrets. Endocrinology 111: 773-780

Baum, M. J., J. A. Canick, M. S. Erskine, C. A. Gallagher, and J. G Shim (1983) Normal differentiation of sexual behavior in male ferrets despite neonatal inhibition of brain aromatase or 5 alpha-reductase activity. Neuroendocrinology 36: 277-284.

Baum, M. J., E. R. Stockman, and L. A. Lundell (1985) Evidence of proceptive without receptive defeminization in the male ferret. Behav. Neurosci., in press.

Canick, J. A., S. A. Tobet, J. H. Shim, and M. J. Baum (1984) The pattern of aromatase and 5 alpha-reductase activity in the brain of the developing ferret and rat. In Metabolism of Hormonal Steroids in Neuroendocrine Structures, L. Martini, ed., pp. 15-20, Raven Press, New York.

Eaton, G. (1970) Effect of a single prepubertal injection of testosterone proprionate on adult bisexual behavior of male hamsters castrated at birth. Endocrinology 87: 934-940.

Erskine, M. S., and M. J. Baum (1982) Plasma concentrations of testosterone and dihydrotestosterone during perinatal development in male and female ferrets. Endocrinology 111: 767-772.

Erskine, M. S., and M. J. Baum (1984) Plasma concentration of estradiol and of estrone during perinatal development in male and female ferrets. J. Endocrinol. 100: 161-166.

Fox, T. O. (1975a) Oestradiol receptor of neonatal mouse brain. Nature 258: 441-444.

Fox, T. O. (1975b) Androgen- and estrogen-binding macromolecules in developing mouse brain: Biochemical and genetic evidence. Proc. Natl. Acad. Sci. U. S. A. 72: 4303-4307.

Fox, T. O., and C. Savakis (1983) Nucleic acid affinity chromatography. In Solid Phase Biochemistry: Analytical and Synthetic Aspects, W H. Scouten, ed., pp. 189-221, John Wiley \& Sons, Inc., New York.

Fox, T. O., K. L. Olsen, C. C. Vito, and S. J. Wieland (1982) Putative steroid receptors: Genetics and development. In Molecular Genetic 
Neuroscience, F. O. Schmitt, S. J. Bird, and F. E. Bloom, eds., pp. 289-306, Raven Press, New York.

Kato, J. (1976) Cytosol and nuclear receptors for 5 alpha-dihydrotestosterone and testosterone in the hypothalamus and hypophysis, and testosterone receptors isolated from neonatal female rat hypothaldmus. J. Steroid Biochem. 7: 1179-1187.

Holbrook, P. G., and M. J. Baum (1983) Characterization of estradiol receptors in brain cytosols from perinatal ferrets. Dev. Brain Res. 7 1-8.

Lieberburg, I., N. MacLusky, and B. S. McEwen (1980) Androgen receptors in the perinatal rat brain. Brain Res. 196: 125-138.

Lowry, O. H., N. J. Rosebrough, A. L. Farr, and R. J. Randall (1951) Protein measurement with the Folin phenol reagent. J. Biol. Chem. 193: 265-275.

MacLusky, N. J., C. Chaptal, and B. S. McEwen (1979a) The development of estrogen receptor systems in the rat brain and pituitary: Postnatal development. Brain Res. 178: 143-160.

MacLusky, N. J., I. Lieberburg, and B. S. McEwen (1979b) The development of estrogen receptor systems in the rat brain: Perinatal development. Brain Res. 178: 129-142.

Pomerantz, S. M., T. O. Fox, S. A. Sholl, C. C. Vito, and R. W. Goy (1985) Androgen and estrogen receptors in fetal rhesus monkey brain and anterior pituitary. Endocrinology, in press.

Salhanick, A. R., C. C. Vito, T. O. Fox, and I. P. Callard (1979) Estrogen-binding proteins in the oviduct of the turtle, Chrysemys picta: Evidence for a receptor species. Endocrinology 105: 1388-1395.
Siegel, L. R., T. O. Fox, and M. Konishi (1983) Androgen and estrogen receptors in zebra finch brain. Soc. Neurosci. Abstr. 9: 1078.

Swanson, H. H. (1970) Effects of castration at birth in hamsters of both sexes on luteinization of ovarian implants, oestrus cycles, and sexual behaviour. J. Reprod. Fertil. 21: 183-186.

Vito, C. C., and J. F. DeBold (1983) Temporal relationship between ontogeny of sex hormone receptors and sexual differentiation in hamster brain. Soc. Neurosci. Abstr. 9: 1076.

Vito, C. C., and T. O. Fox (1979) Embryonic rodent hypothalamus contains estrogen receptors. Science 204: 517-519.

Vito, C. C., and T. O. Fox (1982) Androgen and estrogen receptors in embryonic and neonatal rat brain. Dev. Brain Res. 2: 97-110.

Vito, C. C., S. J. Wieland, and T. O. Fox (1979) Androgen receptors exist throughout the "critical period" of brain sexual differentiation. Nature 282: 308-310.

Vito, C. C., J. F. DeBold, and T. O. Fox (1983) Androgen and estrogen receptors in adult hamster brain. Brain Res. 264: 132-137.

Wieland, S. W., and T. O. Fox (1979) Putative androgen receptors distinguished in wild-type and testicular-feminized $(T f m)$ mice. Cell 17: 781-787.

Wieland, S. W., and T. O. Fox (1981a) Androgen receptors from rat kidney and brain: DNA-binding properties of wild-type and tfm mutant. J. Steroid Biochem. 14: 409-414.

Wieland, S. W., and T. O. Fox (1981b) A DNA-binding fraction of mouse kidney 3-ketosteroid reductase: Comparison with androgen receptors. Steroids 37: $527-538$. 